\title{
IDENTIFIKASI KOMODITAS BASIS TANAMAN PANGAN DAN ARAHAN PENGEMBANGANNYA DI PROVINSI LAMPUNG
}

\section{Identification of Foodcrop Base Commodities and Their Development Direction in Lampung Province}

\section{Santun Risma Pandapotan Sitorus1)*, Bima Wahyu Widodo2), dan Dyah Retno Panuju1)}

\author{
1) Departemen Ilmu Tanah dan Sumberdaya Lahan, Fakultas Pertanian, IPB, Jl. Meranti Kampus IPB Darmaga, \\ Bogor 16680 \\ 2) Alumni Program Studi Manajemen Sumberdaya Lahan Fakultas Pertanian IPB, J1. Meranti Kampus IPB \\ Darmaga, Bogor 16680
}

\begin{abstract}
The agricultural area extensification nowadays is widely performed without prior study of comparative and competitive advantages and potency of agricultural land resources. This study aims: (1) to know food crop basis having a comparative and competitive advantages in Lampung province, (2) to evaluate land suitability of the commodities, (3) to analyze the relationship between the basis index and its land suitability, and (4) to arrange the development direction of basis commodities. Method utilized in identifying the comparative advantage based on Location Quotient (LQ) concept. The competitive advantage identified by using Differentials Shift (DS) of shift share analysis. Land suitability evaluation was performed by matching actual characteristics of the land to criteria developed by FAO. The results showed that mostly the commodities cultivated in each districts, except 3 districts those are Tulang Bawang, Tulang Bawang Barat and Mesuji district did not have any basis crops. The actual land suitability for basis crops for each districts are explained. Lowland rice was widely grown adequately in suitable land in most districts. Development of each basis commodities in relation to land suitability levels in each districts are also explained. This paper also explain development direction of each basis commodities and their hectarage in each district. The unsuitable agricultural land is recommended for conservation area.
\end{abstract}

Keywords: Differential Shift, foodcrops base commodities, land suitability evaluation, Location Quotient

\begin{abstract}
ABSTRAK
Pengembangan wilayah pertanian saat ini banyak dilakukan tanpa penelitian terlebih dahulu dari keunggulan komparatif, kompetitif dan potensi sumberdaya lahan pertanian. Tujuan dari penelitian ini adalah: (1) Mengetahui komoditas basis tanaman pangan yang memiliki keunggulan komparatif dan kompetitif di Provinsi Lampung, (2) mengevaluasi kesesuaian lahan komoditas basis, (3) menganalisis hubungan antara komoditas basis dengan kesesuaian lahan, dan (4) menyusun arahan pengembangan komoditas basis. Metode penelitian yang digunakan dalam mengidentifikasi keunggulan komparatif adalah perhitungan Location Quotient (LQ). Identifikasi keunggulan kompetitif dilakukan menggunakan komponen Differential Shift (DS). Evaluasi kesesuaian lahan dilakukan dengan membandingkan karakteristik tanah dengan kriteria tumbuh tanaman. Analisis korelasi digunakan untuk menganalisis keterkaitan antara komoditas basis dengan tingkat kesesuaian lahan. Hasil penelitian menunjukkan adanya komoditas basis tanaman pangan di masing-masing kabupaten, kecuali di 3 kabupaten yaitu Kabupaten Tulangbawang, Tulang Bawang Barat dan Mesuji yang tidak memiliki komoditas basis. Kesesuaian lahan aktual untuk tanaman komoditas basis di masing-masing kabupaten juga telah dihasilkan. Tanaman padi sawah banyak ditanam di lahan yang cukup sesuai di sebagian besar kabupaten. Pengusahaan masing-masing komoditas basis dikaitkan dengan tingkat kesesuaian lahannya di masing-masing kabupaten juga dikemukakan. Demikian juga arahan pengembangan masing-masing komoditas basis dan luasannya di masing-masing kabupaten. Lahan pada kawasan budidaya pertanian yang tergolong tidak sesuai disarankan digunakan sebagai kawasan konservasi.
\end{abstract}

Kata kunci : Differential Shift, komoditas basis tanaman pangan, evaluasi kesesuaian lahan, Location Quotient

\section{PENDAHULUAN}

Pengembangan wilayah pertanian saat ini banyak dilakukan tanpa penelitian terlebih dahulu keunggulan komparatif, kompetitif dan potensi sumberdaya lahan pertanian. Pertanian sebagai salah satu sektor strategis dalam pengembangan ekonomi domestik dan sumber devisa, berperan penting dalam upaya mendorong pertumbuhan sektor ekonomi. Provinsi Lampung memiliki kegiatan pembangunan yang berorientasi pada potensi sumberdaya alam pada sektor pertanian terutama subsektor tanaman pangan. Penyelenggaraan budidaya tanaman 
pangan memiliki peranan penting bagi perekonomian masyarakat. Untuk mengembangkan perekonomian kerakyatan diperlukan pengembangan komoditas basis yang memiliki nilai tambah bagi pendapatan petani mengingat tingginya tingkat persaingan komoditas basis.

Upaya pengembangan wilayah dilakukan dengan mempertimbangkan daya dukung lahan agar produktivitas lahan optimal. Pengembangan komoditas basis akan mempercepat pertumbuhan ekonomi wilayah dan juga membantu pertumbuhan aktivitas ekonomi komoditas lain. Untuk mengoptimalkan hasil dan tingkat keberlanjutan pertanian dibutuhkan kajian kesesuaian lahan terhadap komoditas basis. Oleh karena itu, diperlukan perencanaan pembangunan pertanian berdasarkan pewilayahan sehingga dapat mengatasi terjadinya persaingan jenis serta produksi komoditas antar wilayah dan peluang pasar akan terjamin.

Penelitian ini bertujuan untuk mengetahui komoditas-komoditas basis tanaman pangan setiap kabupaten/kota di Provinsi Lampung, mengevaluasi kesesuaian lahan komoditas basis tanaman pangan setiap kabupaten/kota di Provinsi Lampung, menganalisis keterkaitan antara komoditas basis dengan kesesuaian lahan di Provinsi Lampung, dan menyusun arahan pengembangan basis komoditas tanaman pangan di setiap kabupaten/ kota di Provinsi Lampung.

\section{BAHAN DAN METODE}

\section{Lokasi Penelitian}

Wilayah studi adalah Provinsi Lampung. Pengolahan data penelitian dilaksanakan di Studio Divisi Perencanaan Pengembangan Wilayah, Departemen Ilmu Tanah dan Sumberdaya Lahan, Fakultas Pertanian, Institut Pertanian Bogor.

\section{Jenis dan Sumber Data serta Alat penelitian}

Data yang digunakan merupakan data sekunder yang diperoleh dari BPS Provinsi Lampung berupa data luas panen dan produksi komoditas tanaman pangan tahun 2006-2010 Provinsi Lampung (BPS Provinsi Lampung, 2007, 2008, 2009, 2010, 2011). Data peta yang digunakan adalah Peta Administrasi Provinsi Lampung skala 1:250,000, Peta Rencana Pola Ruang Provinsi Lampung skala 1:250,000 tahun 2010 dari Bappeda Provinsi Lampung dan Peta Satuan Lahan Lembar Sumatera (1010, 1011, 1110, 1111, 1112) skala 1:250,000 tahun 1989 dari Pusat Penelitian Tanah dan Agroklimat, Bogor. Alat penelitian yang digunakan berupa perangkat lunak pengolahan data dan peta yaitu Microsoft Access, Microsoft Excel, Arcview 3.3, dan Corel Draw 14.

\section{Teknik Analisis Data}

Teknik analisis data untuk masing-masing tujuan penelitian tertera pada Tabel 1 .

Tabel 1. Jenis dan teknik analisis data berdasarkan tujuan penelitian

\begin{tabular}{|c|c|c|c|c|}
\hline No & Tujuan & Jenis Data & Teknik Analisis Data & Keluaran yang diharapkan \\
\hline \multirow[t]{2}{*}{1} & $\begin{array}{l}\text { Mengetahui komoditas basis } \\
\text { Tanaman Pangan }\end{array}$ & $\begin{array}{l}\text { Luas panen tanaman pangan } \\
2006,2007,2008,2009 \text {, dan } \\
2010\end{array}$ & Location Quotient & $\begin{array}{l}\text { LQ setiap tanaman pangan di } \\
\text { kabupaten/kota }\end{array}$ \\
\hline & & $\begin{array}{l}\text { Produksi tanaman pangan } 2006 \\
\text { dan } 2010\end{array}$ & Differential Shift & $\begin{array}{l}\text { DS setiap tanaman pangan di } \\
\text { kabupaten/kota }\end{array}$ \\
\hline 2 & $\begin{array}{l}\text { Mengevaluasi kesesuaian lahan } \\
\text { komoditas basis tanaman } \\
\text { pangan }\end{array}$ & $\begin{array}{l}\text { Peta Administrasi, Penggunaan } \\
\text { Lahan RTRW, Satuan Lembar } \\
\text { 1010, 1110, 1111, dan } 1112 \\
\text { skala 1:250,000 (digital) }\end{array}$ & $\begin{array}{l}\text { Analisis kesesuaian lahan } \\
\text { melalui sistem informasi } \\
\text { geografis }\end{array}$ & $\begin{array}{l}\text { Peta kelas kesesuaian lahan } \\
\text { untuk setiap tanaman pangan }\end{array}$ \\
\hline 3 & $\begin{array}{l}\text { Menganalisis keterkaitan antara } \\
\text { keunggulan komparatif, } \\
\text { kompetitif dan kesesuaian lahan } \\
\text { di Provinsi Lampung }\end{array}$ & $\begin{array}{l}\text { Nilai LQ dan DS setiap tanaman } \\
\text { pangan di kabupaten/kota serta } \\
\text { kelas kesesuaian satuan lahan }\end{array}$ & Analisis Korelasi & $\begin{array}{l}\text { Koefisien korelasi LQ, DS dan } \\
\text { kesesuaian lahan }\end{array}$ \\
\hline 4 & $\begin{array}{l}\text { Menyusun arahan } \\
\text { pengembangan komoditas basis } \\
\text { tanaman pangan }\end{array}$ & $\begin{array}{l}\text { Nilai LQ dan DS setiap tanaman } \\
\text { pangan di kabupaten/kota serta } \\
\text { kelas kesesuaian satuan lahan }\end{array}$ & $\begin{array}{l}\text { Penentuan prioritas arahan } \\
\text { pengembangan komoditas basis } \\
\text { tanaman pangan }\end{array}$ & $\begin{array}{l}\text { Peta arahan pengembangan } \\
\text { komoditas basis tanaman pangan }\end{array}$ \\
\hline
\end{tabular}

\section{Location Quotient (LQ)}

$L Q$ digunakan untuk mengetahui keunggulan komparatif suatu komoditas. Hendayana (2003) menggunakan metode LQ dalam penentuan komoditas unggulan nasional. Hasil perhitungan menunjukkan indikator pemusatan aktivitas perekonomian. Persamaan dari $L Q$ ini adalah (Blakely dan Leigh, 2010):

$$
L Q_{i j}=\frac{X_{i j} / X_{i}}{X_{. j} / X_{. .}}
$$

dimana:

$X_{i j}$ : luas panen komoditas tertentu (i) di suatu kabupaten (j)

$X_{i .}$ : total luas panen (i) komoditas tertentu di provinsi
$X_{. j}$ : total luas panen seluruh komoditas di suatu kabupaten (j)

$X_{. .}$: total luas panen seluruh komoditas di provinsi

\section{Komponen Differential Shift dalam Shift Share Analysis}

Komponen differential shift digunakan untuk mengetahui keunggulan kompetitif suatu komoditas. Hasil perhitungan menunjukkan indikator kemampuan persaingan. Persamaan adalah sebagai berikut (Blakely dan Leigh, 2010):

$$
D S_{i j}=\frac{X_{i j(t l)}}{X_{i j(t 0)}}-\frac{X_{i(t l)}}{X_{i(t 0)}}
$$


dimana:

$X_{i j}$ : produksi komoditas tertentu (i) di suatu kabupaten (j)

$X_{i}$ : total produksi komoditas (i) tertentu di provinsi

${ }_{t l}$ : titik tahun akhir (2010)

to : titik tahun awal (2006)

\section{Analisis Kesesuaian Lahan}

Untuk melihat kesesuaian lahan terhadap komoditas basis dalam wilayah dilakukan evaluasi kesesuaian lahan dengan menggunakan metode FAO (1976), yaitu dengan membandingkan persyaratan tumbuh tanaman yang merupakan komoditas unggulan dengan kualitas lahan. Data spasial yang digunakan dalam analisis adalah peta satuan lahan (land unit) skala 1:250,000. Kriteria karakteristik lahan yang dijadikan parameter dalam penelitian ini meliputi kemiringan lereng, drainase, tekstur, kedalaman efektif, kapasitas tukar kation (KTK), $\mathrm{pH}$, kejenuhan $\mathrm{Al}$, kedalaman sulfidik, dan salinitas. Kriteria kesesuaian lahan yang digunakan merupakan modifikasi kriteria menurut Balai Penelitian Tanah (2003) yaitu dengan hanya menggunakan karakteristik seperti yang dikemukakan diatas. Data untuk penilaian kelas kesesuaian lahan per satuan lahan ini berdasarkan buku keterangan peta satuan lahan dan tanah lembar Sumatera yang didapat dari hasil survei tanah Pusat Penelitian Tanah dan Agroklimat pada tahun 1989.

\section{Analisis Korelasi}

Analisis korelasi adalah teknik analisis statistika yang digunakan untuk mengukur keeratan hubungan antara dua variabel.

Persamaan koefisien korelasi (r) adalah (Walpole, 1993):

$r=\frac{n\left(\sum X Y\right)-\left(\sum X\right)\left(\sum Y\right)}{\left.\sqrt{[n}\left(\sum X^{2}\right)-\left(\sum X\right)^{2}\right]\left[n\left(\sum Y^{2}\right)-\left(\sum Y\right)^{2}\right]}$

dimana:

$\mathrm{n}$ : jumlah responden

$\mathrm{X}$ : variabel 1

Y: variabel 2

$\sum$ : jumlah
Penetapan Arahan Pengembangan Komoditas Basis Tanaman Pangan

Untuk menentukan luas baku diasumsikan penanaman dilakukan sebanyak 2 kali setahun dikurang luas panen yang gagal sehingga indeks pertanaman sebesar $150 \%$. Arahan pengembangan komoditas basis tanaman pangan menggunakan sistem monokultur.

Areal prioritas pengembangan untuk penggunaan lahan pertanian tanaman pangan disusun berdasarkan hasil analisis LQ, DS dan kesesuaian lahan. Komoditas yang memiliki nilai $L Q>1$ dan DS>0 di setiap kota/kabupaten diurutkan sebagai komoditas prioritas dimulai dari yang mempunyai LQ terbesar. Pemilihan lokasi dimulai dari lahan dengan kelas kesesuaian $\mathrm{S} 1$, dilanjutkan pada lahan kelas S2 dan kelas S3 berdasarkan urutan prioritas arahan pengembangan komoditas yang bersangkutan. Dengan demikian arahan pengembangan komoditas basis tanaman pangan dilakukan pada kota/kabupaten basis komoditas tanaman pangan tersebut berdasarkan kelas kesesuaian lahan komoditas tanaman pangan dan di-overlay-kan dengan kawasan budidaya pertanian pada peta rencana pola ruang Provinsi Lampung. Arahan pengembangan komoditas basis tanaman pangan disusun dengan menggunakan beberapa pertimbangan perencanaan yaitu:

1. Pengembangan komoditas basis hanya dilakukan pada kota/ kabupaten basis komoditas tanaman pangan.

2. Alokasi lahan untuk pengembangan komoditas basis berdasarkan urutan komoditas basis dan tingkat kesesuaian lahan untuk komoditas basis tanaman pangan.

3. Pengembangan komoditas basis dilakukan di kawasan budidaya pertanian pada peta rencana pola ruang.

\section{HASIL DAN PEMBAHASAN}

\section{Analisis Komoditas Basis Tanaman Pangan}

\section{Analisis Location Quotient}

Hasil perhitungan analisis LQ pada tahun 20062010 menunjukkan bahwa keunggulan komparatif komoditas tanaman padi sawah memiliki sebaran paling luas dibandingkan komoditas tanaman pangan lain dan diusahakan petani merata di seluruh kota/kabupaten (Tabel 2).

Tabel 2. Nilai rataan koefisien LQ komoditas tanaman pangan berbasis luas panen rata-rata kabupaten/kota di Provinsi Lampung Periode Tahun 2006-2010

\begin{tabular}{|c|c|c|c|c|c|c|c|c|}
\hline Kabupaten/ Kota & $\begin{array}{c}\text { Padi } \\
\text { Sawah }\end{array}$ & $\begin{array}{c}\text { Padi } \\
\text { Ladang }\end{array}$ & Jagung & $\begin{array}{c}\text { Ubi } \\
\text { Kayu }\end{array}$ & $\begin{array}{c}\text { Ubi } \\
\text { Jalar }\end{array}$ & $\begin{array}{c}\text { Kacang } \\
\text { Tanah }\end{array}$ & Kedelai & $\begin{array}{c}\text { Kacang } \\
\text { Hijau }\end{array}$ \\
\hline Lampung Barat & 2.22 & 1.27 & 0.21 & 0.06 & 3.23 & 1.35 & 1.26 & 0.64 \\
\hline Lampung Timur & 0.85 & 0.51 & 1.57 & 0.66 & 0.53 & 0.48 & 0.53 & 0.58 \\
\hline Lampung Tengah & 0.81 & 1.12 & 0.95 & 1.34 & 0.77 & 0.88 & 0.85 & 0.91 \\
\hline Lampung Utara & 0.52 & 2.06 & 0.94 & 1.54 & 1.67 & 1.85 & 1.06 & 1.66 \\
\hline Way Kanan & 1.06 & 2.49 & 0.60 & 0.95 & 1.05 & 3.73 & 2.40 & 3.90 \\
\hline Bandar Lampung & 1.95 & 0.88 & 0.26 & 0.35 & 7.88 & 2.38 & 1.94 & 0.96 \\
\hline Metro & 2.14 & 0.07 & 0.46 & 0.12 & 1.78 & 0.89 & 1.75 & 1.68 \\
\hline Tanggamus \& Pringsewu & 2.00 & 0.78 & 0.47 & 0.12 & 2.10 & 1.18 & 3.59 & 1.30 \\
\hline Lampung Selatan \& Pesawaran & 1.06 & 0.80 & 1.62 & 0.19 & 0.93 & 0.69 & 0.88 & 0.72 \\
\hline Tulang Bawang, Mesuji, Tulang Bawang Barat & 1.07 & 0.50 & 0.20 & 2.03 & 0.68 & 0.54 & 0.38 & 0.48 \\
\hline
\end{tabular}

Hal ini disebabkan tanaman padi merupakan bahan pangan pokok masyarakat di Indonesia. Nilai LQ tertinggi terdapat pada komoditas ubi jalar di Kota Bandar Lampung (7.88) disebabkan luasan di kota tersebut besar 
sedangkan pembandingnya yaitu luas keseluruhan provinsi relatif kecil. Hal ini dapat disebabkan permintaan ubi jalar dan diversifikasi pangan di Kota Bandar Lampung tinggi.

\section{Differential Shift (DS) dalam Shift Share Analysis (SSA)}

Hasil perhitungan komponen DS pada tahun 2006 dan 2010 masing-masing kabupaten/kota menunjukkan bahwa komoditas jagung memiliki tingkat persaingan paling tinggi untuk dikembangkan dibandingkan komoditas tanaman pangan lain disebabkan pertumbuhan produksi tanaman jagung lebih tinggi dibandingkan pertumbuhan produksi komoditas tanaman pangan lainnya di Provinsi Lampung (Tabel 3). Hal ini diduga disebabkan tanaman jagung mengalami kenaikan permintaan dunia karena produsen jagung dunia seperti Amerika Serikat dan China mengembangkan jagung sebagai energi alternatif (bioethanol) secara intensif (Imron, 2010).

Tabel 3. Hasil analisis Differential Shift komoditas tanaman pangan berbasis produksi kabupaten/kota di Provinsi Lampung periode tahun 2006 dan 2010

\begin{tabular}{|c|c|c|c|c|c|c|c|c|}
\hline Kabupaten/ Kota & $\begin{array}{c}\text { Padi } \\
\text { Sawah }\end{array}$ & $\begin{array}{c}\text { Padi } \\
\text { Ladang }\end{array}$ & Jagung & $\begin{array}{c}\text { Ubi } \\
\text { Kayu }\end{array}$ & Ubi Jalar & $\begin{array}{l}\text { Kacang } \\
\text { Tanah }\end{array}$ & Kedelai & $\begin{array}{c}\text { Kacang } \\
\text { Hijau }\end{array}$ \\
\hline Lampung Barat & 0.1169 & 1.0641 & 5.0147 & 0.1679 & 0.2597 & -0.0533 & -0.9689 & 0.4146 \\
\hline Lampung Timur & -0.0689 & -0.0646 & 0.0464 & -0.2455 & -0.1707 & -0.5399 & -0.1975 & -0.0248 \\
\hline Lampung Tengah & -0.0385 & -0.1022 & 0.0080 & 0.3354 & -0.0676 & -0.5015 & -0.3043 & -0.0771 \\
\hline Lampung Utara & 0.1171 & 0.1105 & -0.2717 & 0.6526 & 0.9894 & 1.4878 & 8.5255 & 0.6150 \\
\hline Way Kanan & -0.2589 & -0.0026 & 0.0024 & -0.4446 & 0.1088 & -0.4236 & -1.2892 & -0.2398 \\
\hline Bandar Lampung & -0.0711 & -0.6433 & -1.1511 & -0.4615 & 0.0010 & -0.8904 & -2.0381 & -0.3908 \\
\hline Metro & 0.0284 & -1.0781 & 0.1183 & -0.8254 & -0.3595 & -0.7069 & -1.3013 & 0.9592 \\
\hline Lampung Selatan \& Pesawaran & 0.1158 & 0.0965 & 0.0578 & -0.7515 & -0.4660 & 2.4613 & 8.2079 & -0.0615 \\
\hline Tulang Bawang, Mesuji, \& Tulang Bawang Barat & -0.0499 & -0.3180 & -0.9547 & -0.2330 & -0.1110 & -0.9139 & -1.1757 & -0.1195 \\
\hline
\end{tabular}

Sumber: BPS, (2006) dan (2010), diolah

Gambar 1 menunjukkan komoditas basis dan non basis di setiap kabupaten/kota. Kuadran 1 (kanan atas) merupakan wilayah yang mempunyai keunggulan komparatif dan kompetitif. Kuadran 2 (kiri atas) merupakan wilayah yang memiliki keunggulan komparatif namun tidak keunggulan kompetitif.

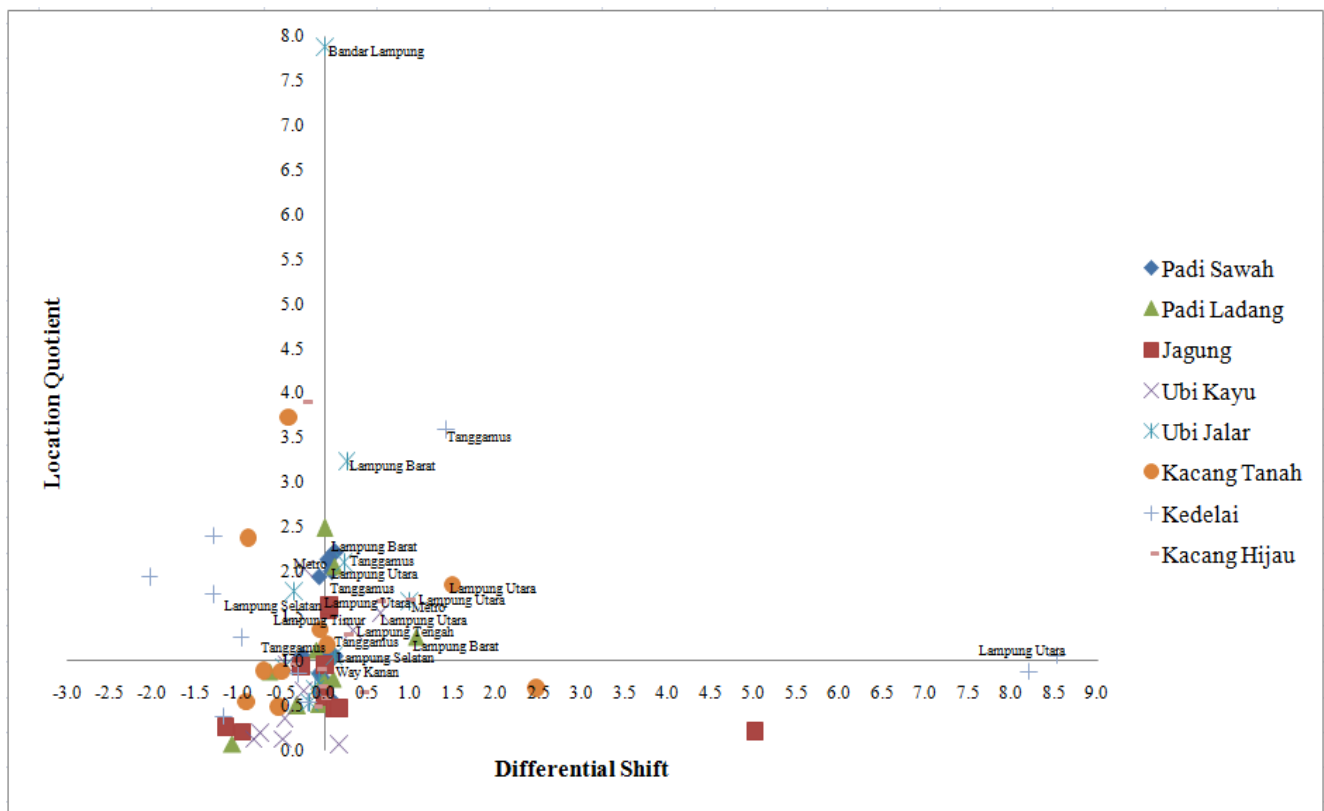

Gambar 1. Scatter Plot nilai Location Quotient dan Differential Shift komoditas tanaman pangan di Provinsi Lampung

Tabel 4. Komoditas basis tanaman pangan untuk tiap kabupaten/kota di Provinsi Lampung.

\begin{tabular}{ll}
\hline \multicolumn{1}{c}{ Kabupaten/kota } & \multicolumn{1}{c}{ Komoditas Basis Tanaman Pangan } \\
\hline Lampung Barat & Ubi Jalar, Padi Sawah, Padi Ladang \\
Lampung Timur & Jagung \\
Lampung Tengah & Ubi Kayu \\
Lampung Utara & Padi Ladang, Kacang Tanah, Ubi Jalar, Kacang Hijau, Ubi Kayu, Kedelai \\
Way Kanan & Ubi Jalar \\
Bandar Lampung & Ubi Jalar \\
Metro & Padi Sawah, Kacang Hijau \\
Tanggamus \& Pringsewu & Kedelai, Ubi Jalar, Padi Sawah, Kacang Hijau, Kacang Tanah \\
Lampung Selatan \& Pesawaran & Jagung, Padi Sawah \\
Tulang Bawang, Mesuji, \& Tulang Bawang Barat & Tidak Ada \\
\hline
\end{tabular}


Kuadran 3 (kiri bawah) merupakan wilayah yang tidak memiliki keunggulan komparatif maupun kompetitif. Kuadran 4 (kanan bawah) merupakan wilayah yang memiliki keunggulan kompetitif namun tidak komparatif. Komoditas basis tanaman pangan untuk tiap kabupaten/kota di Provinsi Lampung tertera pada Tabel 4.

\section{Evaluasi Kesesuaian Lahan Komoditas Basis Tanaman Pangan}

Kesesuaian lahan aktual untuk tanaman padi sawah terdiri lahan Tidak Sesuai (N) yang sebagian besar terdapat di Kabupaten Lampung Barat, Kabupaten Tanggamus dan Pringsewu, dan Kabupaten Lampung Selatan serta Pesawaran. Hal ini karena sebagian besar faktor pembatasnya adalah lereng $(\mathrm{Ne})$. Kelas kesesuaian Sesuai Marjinal $\left(\mathrm{S}_{3}\right)$ sebagian besar terdapat di Kota Metro. Hal ini karena sebagian besar faktor pembatasnya adalah lereng dan $\mathrm{pH}$ (S3ef) (Tabel 5 dan Gambar 2a).

Kesesuaian lahan aktual di Provinsi Lampung untuk tanaman padi ladang sebagian besar terdiri lahan Sesuai Marjinal (S3) yang terdapat di Kabupaten Lampung Barat dengan faktor pembatasnya adalah lereng dan kemasaman tanah (S3ef) serta media perakaran (S3r). Kelas kesesuaian Sesuai (S2) yang sebagian besar terdapat di Kabupaten Lampung Utara dengan sebagian besar faktor pembatasnya adalah lereng dan $\mathrm{pH}$ (Tabel 6 dan Gambar 2b).

Tabel 5. Kelas kesesuaian lahan aktual untuk tanaman basis padi sawah di Provinsi Lampung

\begin{tabular}{|c|c|c|c|c|c|c|c|c|}
\hline \multirow{2}{*}{$\begin{array}{c}\text { Kelas Kesesuaian } \\
\text { Lahan }\end{array}$} & \multicolumn{2}{|c|}{ Metro } & \multicolumn{2}{|c|}{ Lampung Barat } & \multicolumn{2}{|c|}{ Lampung Selatan \& Pesawaran } & \multicolumn{2}{|c|}{ Tanggamus \& Pringsewu } \\
\hline & ha & $\%$ & ha & $\%$ & ha & $\%$ & ha & $\%$ \\
\hline $\mathrm{S} 2 \mathrm{r}$ & 0.00 & 0.00 & 70.61 & 0.27 & 0.00 & 0.00 & $4,721.83$ & 4.21 \\
\hline S2rf & 494.19 & 13.25 & $4,069.47$ & 15.59 & $9,727.91$ & 9.18 & $8,210.31$ & 7.32 \\
\hline $\mathrm{S} 2 \mathrm{rx}$ & 0.00 & 0.00 & 0.00 & 0.00 & 0.00 & 0.00 & 650.05 & 0.58 \\
\hline S3e & 19.71 & 0.53 & 81.48 & 0.31 & $24,604.53$ & 23.23 & $12,102.46$ & 10.80 \\
\hline S3ef & $2,776.24$ & 74.46 & 0.00 & 0.00 & $3,963.36$ & 3.74 & $1,722.20$ & 1.54 \\
\hline S3er & 0.00 & 0.00 & 82.46 & 0.32 & 0.00 & 0.00 & 0.00 & 0.00 \\
\hline $\mathrm{S} 3 \mathrm{r}$ & 0.00 & 0.00 & $2,093.50$ & 8.02 & $6,005.48$ & 5.67 & $1,503.41$ & 1.34 \\
\hline $\mathrm{Nr}$ & 0.00 & 0.00 & 165.73 & 0.64 & $1,347.14$ & 1.27 & 15.41 & 0.01 \\
\hline Nex & 0.00 & 0.00 & 0.00 & 0.00 & $12,399.28$ & 11.71 & 0.00 & 0.00 \\
\hline $\mathrm{Nx}$ & 0.00 & 0.00 & 0.00 & 0.00 & 835.00 & 0.79 & 0.00 & 0.00 \\
\hline
\end{tabular}

Tabel 6. Kelas kesesuaian lahan aktual untuk tanaman basis padi ladang di Provinsi Lampung

\begin{tabular}{lrrrr}
\hline \multirow{2}{*}{$\begin{array}{c}\text { Kelas } \\
\text { Kesesuaian } \\
\text { Lahan }\end{array}$} & \multicolumn{2}{c}{ Lampung Barat } & \multicolumn{2}{c}{ Lampung Utara } \\
\cline { 2 - 5 } & ha & $\%$ & ha & $\%$ \\
\hline S1 & $1,602.89$ & 6.14 & 0.00 & 0.00 \\
S2e & $2,660.93$ & 10.20 & $3,936.04$ & 6.28 \\
S2ef & 806.01 & 3.09 & $25,431.15$ & $\mathbf{4 0 . 6 0}$ \\
S2f & 81.48 & 0.31 & $7,843.18$ & 12.52 \\
S3e & 17.31 & 0.07 & 0.00 & 0.00 \\
S3ef & $4,432.65$ & 16.98 & 185.08 & 0.30 \\
S3er & 155.69 & 0.60 & 0.00 & 0.00 \\
S3r & $6,316.05$ & 24.20 & $5,237.35$ & 8.36 \\
S3f & 122.25 & 0.47 & $16,042.12$ & 25.61 \\
Ne & $9,736.54$ & $\mathbf{3 7 . 3 1}$ & 41.95 & 0.07 \\
Nr & 165.73 & 0.64 & 0.00 & 0.00 \\
Nx & 0.00 & 0.00 & $3,927.48$ & 6.27 \\
\hline
\end{tabular}

Kesesuaian lahan aktual di Provinsi Lampung untuk tanaman ubi kayu sebagian besar terdiri lahan Sesuai Marjinal (S3) terdapat di Kabupaten Lampung Tengah dan Kabupaten Lampung Utara dengan faktor pembatasnya adalah kemasaman tanah (Tabel 7 dan Gambar 3a).

Kesesuaian lahan aktual di Provinsi Lampung untuk tanaman ubi jalar sebagian besar terdiri lahan Sesuai Marjinal (S3) terdapat di Kabupaten Lampung Utara dan Kabupaten Way Kanan dengan faktor pembatasnya sebagian besar adalah kemasaman tanah. Kelas kesesuaian Tidak Sesuai (N) sebagian besar terdapat di Kabupaten Lampung Barat sebesar dengan faktor pembatas adalah kemiringan lereng (Tabel 8 dan Gambar 3b).
Tabel 7. Kelas kesesuaian lahan aktual untuk tanaman basis ubi kayu di Provinsi Lampung

\begin{tabular}{lrrrr}
\hline \multirow{2}{c}{$\begin{array}{c}\text { Kelas } \\
\text { Kesesuaian } \\
\text { Lahan }\end{array}$} & \multicolumn{2}{c}{ Lampung Tengah } & \multicolumn{2}{c}{ Lampung Utara } \\
\cline { 2 - 5 } & ha & $\%$ & ha & $\%$ \\
\hline S2e & 661.19 & 0.41 & $3,936.04$ & 6.28 \\
S2ef & $3,977.36$ & 2.46 & 0.00 & 0.00 \\
S2f & $1,991.29$ & 1.23 & 0.00 & 0.00 \\
S2rf & $3,425.37$ & 2.12 & 0.00 & 0.00 \\
S3er & 572.73 & 0.35 & 0.00 & 0.00 \\
S3r & $13,803.70$ & 8.55 & 592.81 & 0.95 \\
S3f & $104,257.70$ & $\mathbf{6 4 . 5 8}$ & $49,316.45$ & $\mathbf{7 8 . 7 2}$ \\
S3rf & $2,237.47$ & 1.39 & $4,644.54$ & 7.41 \\
Ne & $1,044.32$ & 0.65 & 227.02 & 0.36 \\
Nr & 1.07 & 0.00 & 0.00 & 0.00 \\
Nx & $28,888.53$ & 17.89 & $3,927.48$ & 6.27 \\
Nrx & 577.00 & 0.36 & 0.00 & 0.00 \\
\hline
\end{tabular}

Kesesuaian lahan aktual di Provinsi Lampung untuk tanaman jagung, sebagian besar terdiri atas lahan Cukup Sesuai (S2) terdapat di Kabupaten Lampung Timur, Kabupaten Lampung Selatan dan Pesawaran dengan faktor pembatas sebagian besar adalah kemasaman tanah (S2f) (Tabel 9 dan Gambar 4a).

Kesesuaian lahan aktual di Provinsi Lampung untuk tanaman kedelai dan kacang tanah, sebagian besar terdiri atas lahan Cukup Sesuai (S2) terdapat di Kabupaten Lampung Utara dengan faktor pembatas adalah kemasaman tanah (S2f). Kelas kesesuaian Sesuai Marjinal (S3) sebagian besar terdapat di Kabupaten Tanggamus dan Pringsewu serta Kabupaten Lampung Utara dengan faktor pembatas adalah kemasaman tanah, lereng dan media perakaran (Tabel 10 dan Gambar 4b). 


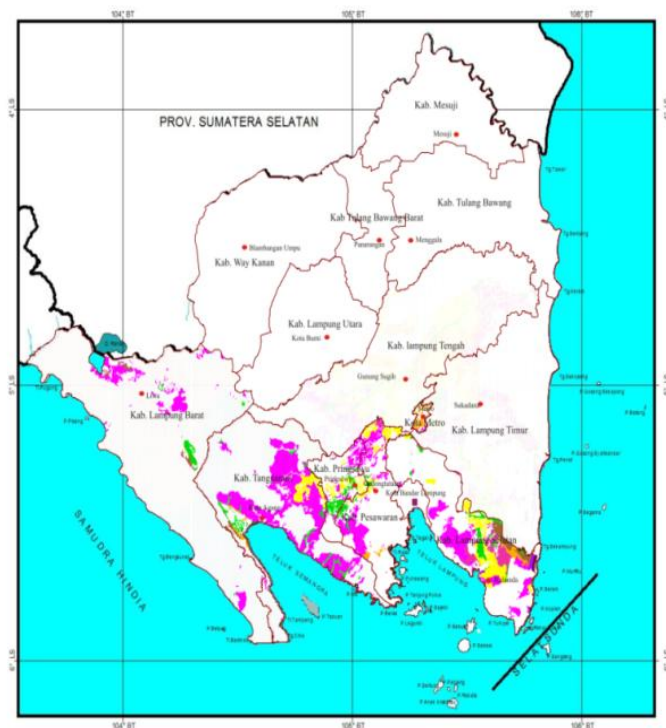

(a)
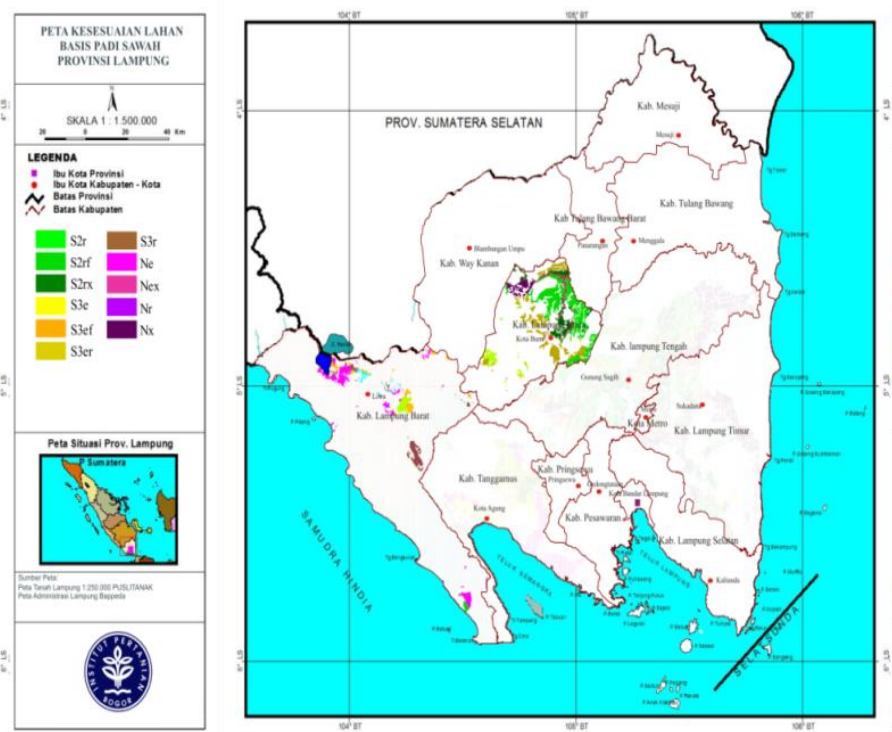

(b)

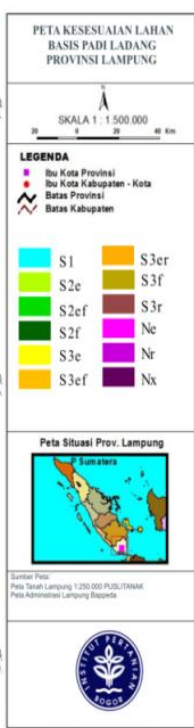

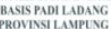

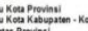

$\mathrm{s1} \square \mathrm{s} 3 \mathrm{se}_{2}$

政3

Gambar 2. Peta kelas kesesuaian lahan untuk tanaman basis padi sawah (a) dan padi ladang (b) di Provinsi Lampung

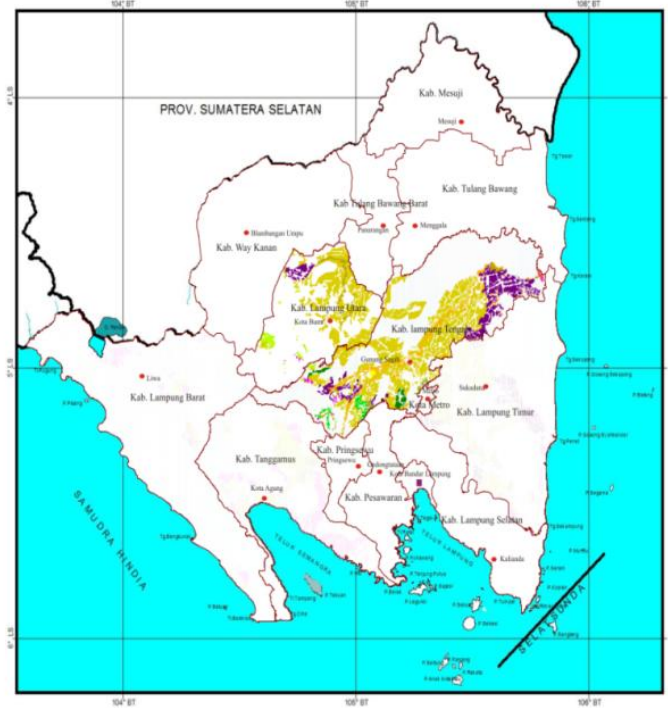

(a)
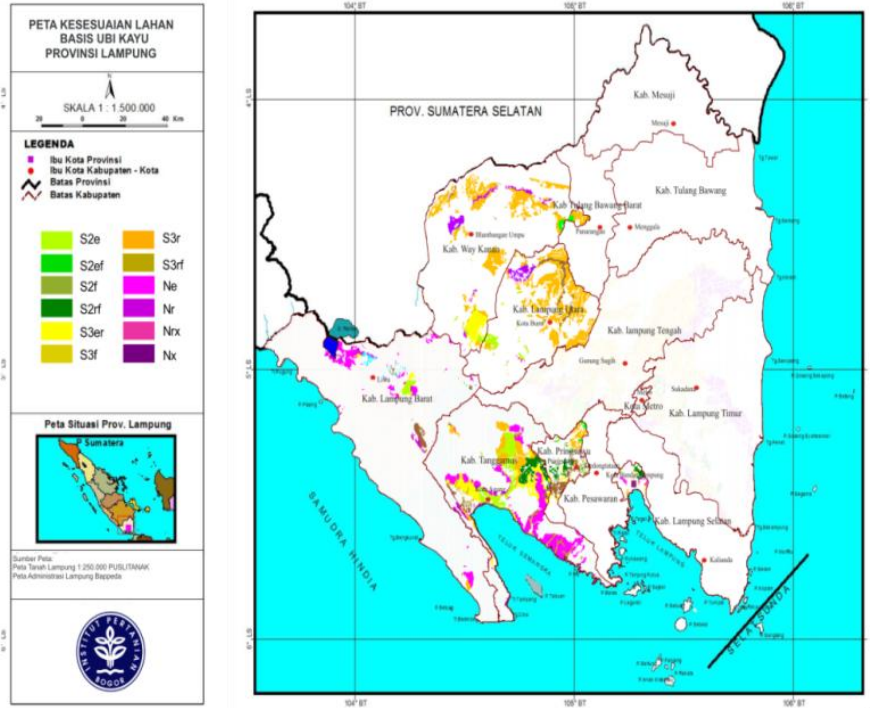

(b)

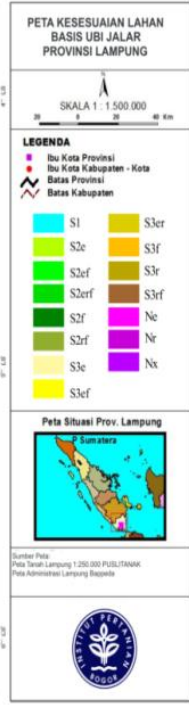

Gambar 3. Peta kelas kesesuaian lahan untuk tanaman basis ubi kayu (a) dan ubi jalar (b) di Provinsi Lampung

Tabel 8. Kelas kesesuaian lahan aktual untuk tanaman basis ubi jalar di Provinsi Lampung

\begin{tabular}{|c|c|c|c|c|c|c|c|c|c|c|}
\hline \multirow{2}{*}{$\begin{array}{c}\text { Kelas } \\
\text { Kesesuaian } \\
\text { Lahan }\end{array}$} & \multicolumn{2}{|c|}{ Bandar Lampung } & \multicolumn{2}{|c|}{ Lampung Barat } & \multicolumn{2}{|c|}{ Lampung Utara } & \multicolumn{2}{|c|}{ Way Kanan } & \multicolumn{2}{|c|}{$\begin{array}{l}\text { Tanggamus dan } \\
\text { Pringsewu }\end{array}$} \\
\hline & ha & $\%$ & ha & $\%$ & ha & $\%$ & ha & $\%$ & ha & $\%$ \\
\hline $\mathrm{S} 1$ & 0.00 & 0.00 & $1,602.89$ & 6.14 & 0.00 & 0.00 & 0.00 & 0.00 & 0.00 & 0.00 \\
\hline $\mathrm{S} 2 \mathrm{e}$ & 114.02 & 3.53 & $2,660.93$ & 10.20 & $3,936.04$ & 6.28 & $1,679.79$ & 2.57 & $14,373.38$ & 12.82 \\
\hline S2ef & 186.50 & 5.78 & 0.00 & 0.00 & 0.00 & 0.00 & $1,620.59$ & 2.48 & $1,097.46$ & 0.98 \\
\hline $\mathrm{S} 2 \mathrm{f}$ & $1,208.61$ & 37.45 & 81.48 & 0.31 & 0.00 & 0.00 & 0.00 & 0.00 & $10,132.67$ & 9.04 \\
\hline S2rf & 0.00 & 0.00 & 82.46 & 0.32 & 0.00 & 0.00 & 21.75 & 0.03 & $1,856.37$ & 1.66 \\
\hline S2erf & 0.00 & 0.00 & 0.00 & 0.00 & 0.00 & 0.00 & 0.00 & 0.00 & 45.59 & 0.04 \\
\hline $\mathrm{S} 3 \mathrm{e}$ & 0.00 & 0.00 & 17.31 & 0.07 & 0.00 & 0.00 & 0.00 & 0.00 & $1,061.37$ & 0.95 \\
\hline S3ef & 250.78 & 7.77 & $1,228.04$ & 4.71 & 0.00 & 0.00 & $8,939.26$ & 13.68 & $16,207.23$ & 14.46 \\
\hline S3er & 76.59 & 2.37 & 0.00 & 0.00 & 0.00 & 0.00 & 0.00 & 0.00 & 0.00 & 0.00 \\
\hline S3f & 517.82 & 16.05 & 928.26 & 3.56 & $49,316.45$ & 78.72 & $43,539.24$ & 66.64 & $19,208.52$ & 17.14 \\
\hline $\mathrm{S} 3 \mathrm{r}$ & 0.00 & 0.00 & 70.61 & 0.27 & 592.81 & 0.95 & $1,215.47$ & 1.86 & $4,838.01$ & 4.32 \\
\hline S3rf & 0.00 & 0.00 & $4,069.47$ & 15.59 & $4,644.54$ & 7.41 & 882.06 & 1.35 & $8,094.13$ & 7.22 \\
\hline $\mathrm{Ne}$ & 871.24 & 27.00 & $13,096.84$ & 50.18 & 227.02 & 0.36 & 408.97 & 0.63 & $33,017.43$ & 29.45 \\
\hline $\mathrm{Nr}$ & 1.48 & 0.05 & $2,259.24$ & 8.66 & 0.00 & 0.00 & $3,719.27$ & 5.69 & $1,518.82$ & 1.35 \\
\hline $\mathrm{Nx}$ & 0.00 & 0.00 & 0.00 & 0.00 & $3,927.48$ & 6.27 & $3,308.20$ & 5.06 & 650.05 & 0.58 \\
\hline
\end{tabular}




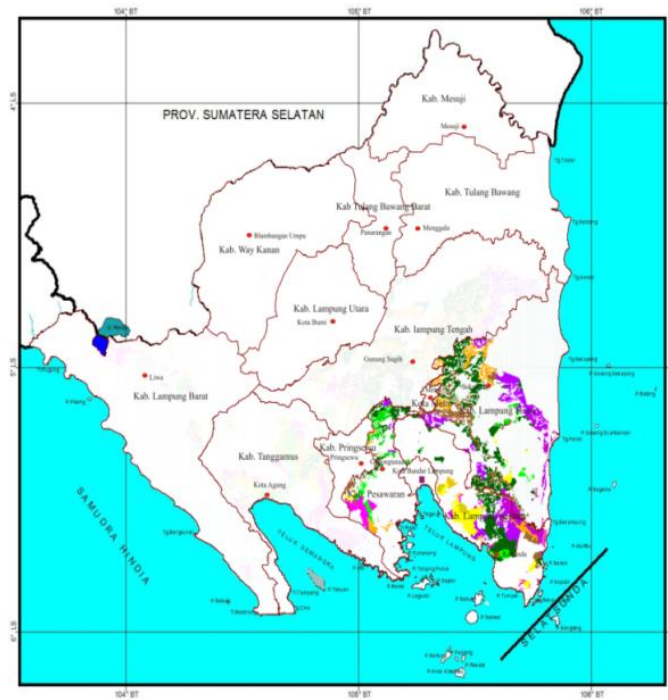

(a)
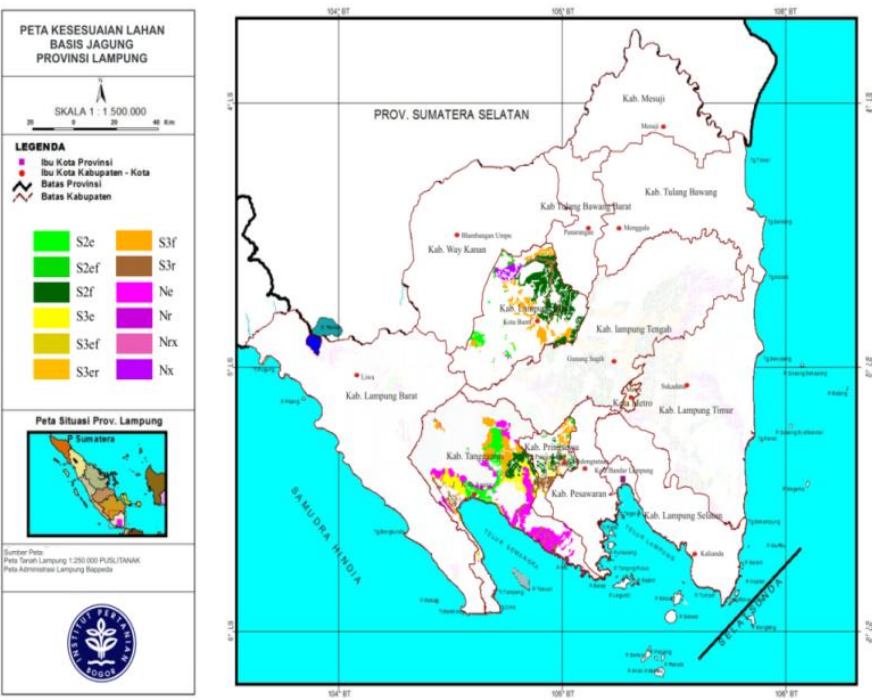

(b)

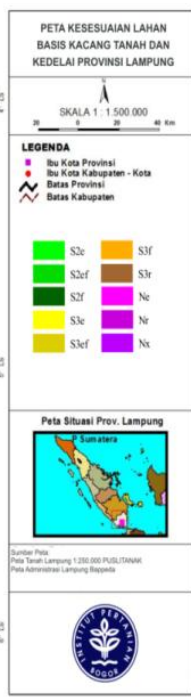

Gambar 4. Peta kelas kesesuaian lahan untuk tanaman basis jagung (a) dan kedelai dan kacang tanah (b) di Provinsi Lampung
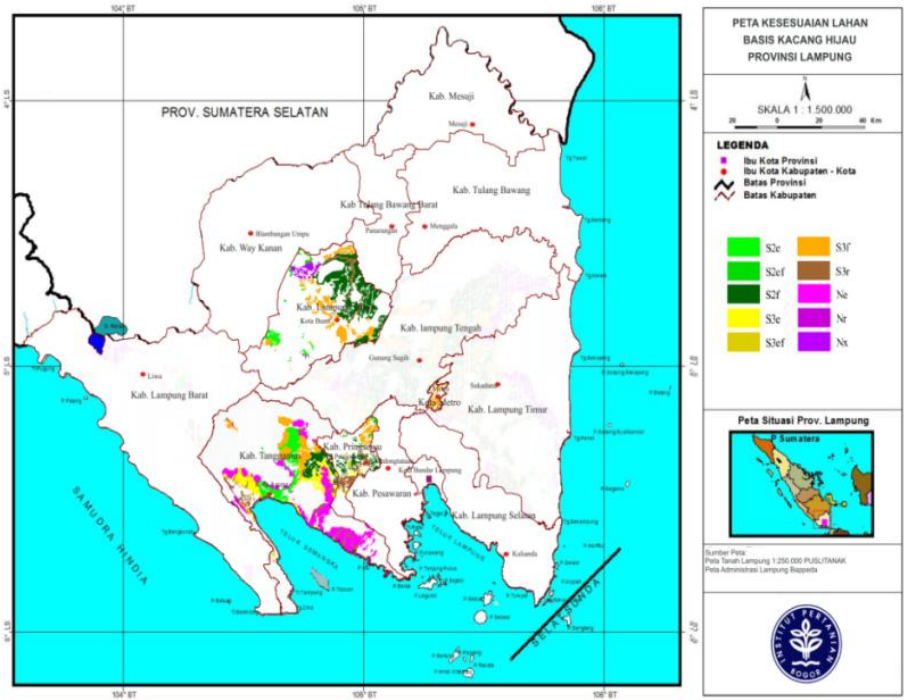

Gambar 5. Peta kelas kesesuaian lahan untuk tanaman basis kacang hijau di Provinsi Lampung

Tabel 9. Kelas kesesuaian lahan aktual untuk tanaman basis jagung di Provinsi Lampung

\begin{tabular}{|c|c|c|c|c|}
\hline \multirow{2}{*}{$\begin{array}{c}\text { Kelas } \\
\text { Kesesuaian } \\
\text { Lahan }\end{array}$} & \multicolumn{2}{|c|}{$\begin{array}{c}\text { Lampung Selatan dan } \\
\text { Pesawaran }\end{array}$} & \multicolumn{2}{|c|}{ Lampung Timur } \\
\hline & ha & $\%$ & ha & $\%$ \\
\hline S2e & $5,710.34$ & 5.39 & $1,446.33$ & 1.43 \\
\hline S2ef & $8,467.91$ & 8.00 & $2,444.82$ & 2.41 \\
\hline S2f & $28,192.47$ & 26.62 & $35,822.16$ & 35.32 \\
\hline S3e & $13,765.94$ & 13.00 & $1,676.28$ & 1.65 \\
\hline S3ef & $5,278.77$ & 4.98 & 0.00 & 0.00 \\
\hline S3er & $1,175.76$ & 1.11 & 0.00 & 0.00 \\
\hline S3f & $4,728.21$ & 4.46 & $12,367.48$ & 12.19 \\
\hline $\mathrm{S} 3 \mathrm{r}$ & $9,428.56$ & 8.90 & $18,851.28$ & 18.59 \\
\hline $\mathrm{Ne}$ & $8,577.50$ & 8.10 & 0.00 & 0.00 \\
\hline $\mathrm{Nr}$ & $7,352.62$ & 6.94 & $8,290.12$ & 8.17 \\
\hline $\mathrm{Nx}$ & $12,399.28$ & 11.71 & $20,038.67$ & 19.76 \\
\hline Nrx & 835.00 & 0.79 & 493.54 & 0.49 \\
\hline
\end{tabular}

Kesesuaian lahan aktual di Provinsi Lampung untuk tanaman kacang hijau sebagian besar terdiri lahan Sesuai Marjinal (S3) terdapat di Kota Metro dengan faktor pembatas adalah kemasaman tanah (S3f). Kelas kesesuaian
Cukup Sesuai (S2) sebagian besar terdapat di Kabupaten Lampung Utara dengan faktor pembatas adalah kemasaman tanah (S2f). Kelas kesesuaian Tidak Sesuai (N) terdapat di Kabupaten Tanggamus dan Pringsewu faktor pembatas sebagian besar adalah kemiringan lereng (Tabel 11 dan Gambar 5).

Tabel 10. Kelas kesesuaian lahan aktual untuk tanaman basis kedelai dan kacang tanah di Provinsi Lampung

\begin{tabular}{lrrrr}
\hline \multirow{2}{*}{$\begin{array}{c}\text { Kelas Kesesuaian } \\
\text { Lahan }\end{array}$} & \multicolumn{2}{c}{ Lampung Utara } & \multicolumn{2}{c}{ Tanggamus dan } \\
Pringsewu
\end{tabular}


Tabel 11. Kelas kesesuaian lahan aktual untuk tanaman basis kacang hijau di Provinsi Lampung.

\begin{tabular}{lrrrrrr}
\hline \multirow{2}{*}{$\begin{array}{c}\text { Kelas } \\
\text { Kesesuaian }\end{array}$} & \multicolumn{2}{c}{ Metro } & \multicolumn{3}{c}{ Lampung Utara } & \multicolumn{2}{c}{$\begin{array}{c}\text { Tanggamus dan } \\
\text { Pringsewu }\end{array}$} \\
\cline { 2 - 7 } \multicolumn{1}{c}{ Lahan } & ha & $\%$ & ha & $\%$ & ha & $\%$ \\
\hline S2e & 0.00 & 0.00 & $3,936.04$ & 6.28 & $14,373.38$ & 12.82 \\
S2ef & 0.00 & 0.00 & $1,146.79$ & 1.83 & $1,097.46$ & 0.98 \\
S2f & 354.37 & 9.50 & $32,127.54$ & $\mathbf{5 1 . 2 9}$ & $12,102.46$ & 10.80 \\
S3e & 0.00 & 0.00 & 0.00 & 0.00 & $14,828.62$ & 13.23 \\
S3ef & 0.00 & 0.00 & 0.00 & 0.00 & $2,439.98$ & 2.18 \\
S3f & $2,776.24$ & $\mathbf{7 4 . 4 6}$ & $16,042.12$ & 25.61 & $19,095.10$ & 17.03 \\
S3r & 598.03 & 16.04 & $5,237.35$ & 8.36 & $13,627.78$ & 12.16 \\
Ne & 0.00 & 0.00 & 227.02 & 0.36 & $33,017.43$ & $\mathbf{2 9 . 4 5}$ \\
Nr & 0.00 & 0.00 & 0.00 & 0.00 & $1,518.82$ & 1.35 \\
Nx & 0.00 & 0.00 & $3,927.48$ & 6.27 & 0.00 & 0.00 \\
\hline
\end{tabular}

\section{Keterkaitan Keunggulan Komparatif, Kompetitif, dan Kelas Kesesuaian Lahan}

Hasil analisis korelasi pada beberapa variabel menunjukkan tidak terdapat korelasi sempurna namun terdapat 13 dari 72 hasil analisis yang memiliki korelasi kuat. Tanaman padi sawah pada variabel keunggulan komparatif (LQ) terhadap luas lahan dengan kesesuaian S2 (Cukup Sesuai) memiliki korelasi yang kuat artinya tanaman padi sawah dibudidayakan secara luas pada lahan tersebut dan hampir merata di seluruh kabupaten/ kota. Akan tetapi variabel LQ dan luas lahan berkesesuaian S3 (Sesuai Marjinal) memiliki korelasi kuat negatif artinya lahan dengan areal tanam/panen luas saat ini cenderung tidak berlokasi di lahan berkelas S3. Hal ini diduga dipengaruhi penggunaan lahan lainnya di lahan tersebut atau pengembangan padi sawah diprioritaskan pada kelas kesesuaian yang lebih tinggi yaitu $\mathrm{S} 2$.

Variabel keunggulan kompetitif (DS) padi ladang berkorelasi positif dengan luas lahan berkesesuaian S1 (Sangat Sesuai) dan N (Tidak Sesuai). Besarnya korelasi antara keunggulan kompetitif dengan kelas S1 menggambarkan pola usaha tani yang semakin diintensifkan di lahan sesuai. Korelasi dengan lahan Tidak Sesuai mengindikasikan upaya ekstensifikasi di lokasi yang kurang potensial. Hal ini dapat menyebabkan degradasi lahan yaitu di Kabupaten Lampung Barat.
Indeks keunggulan komparatif (LQ) jagung berkorelasi positif dengan luas lahan berkesesuaian S2 (Cukup Sesuai). Fenomena ini dijumpai di Kabupaten Lampung Utara. Selanjutnya variabel keunggulan kompetitif (DS) jagung berkorelasi positif dengan luas lahan berkesesuaian S1 (Sangat Sesuai) dan kelas kesesuaian N (Tidak Sesuai) dan fenomena ini dijumpai di Kabupaten Lampung Barat.

Tanaman ubi kayu pada variabel LQ berkorelasi positif dengan variabel DS nya yang mengindikasikan bahwa tanaman ubi kayu dibudidayakan pada luas panen yang besar dengan pertumbuhan produksi yang tinggi. Hal ini diduga disebabkan tanaman ubi kayu memiliki jumlah permintaan dan peningkatan produksi yang tinggi. Salah satu permintaan tanaman ubi kayu adalah sebagai bahan baku industri tepung tapioka di Provinsi Lampung. Selanjutnya variabel indeks LQ dan luas lahan berkesesuaian S3 memiliki korelasi positif, meskipun pada variabel LQ terhadap luas lahan berkesesuaian S2 yang memiliki korelasi negatif yaitu di Kabupaten Lampung Tengah dan Lampung Utara.

Tanaman ubi jalar pada variabel LQ berkorelasi positif dengan luas lahan berkesesuaian S2 (Cukup Sesuai) memiliki korelasi kuat. Akan tetapi variabel LQ berkorelasi negatif dengan luas lahan berkesesuaian S3 (Sesuai Marjinal) yang ditunjukkan salah satunya di Kota Bandar Lampung. Tanaman kedelai pada variabel DS terhadap kelas kesesuaian S2 (Cukup Sesuai) memiliki korelasi kuat di Kabupaten Lampung Utara

Berdasarkan uji signifikansi koefisien korelasi dengan nilai t-tabel sebesar 1.86 terdapat enam hasil analisis koefisien yang signifikan pada tingkat kepercayaan $95 \%$. Koefisien korelasi yang signifikan adalah: tanaman padi sawah pada variabel LQ dengan luas lahan berkesesuaian $\mathrm{S} 3$, tanaman padi ladang pada variabel DS dengan luas lahan berkesesuaian $\mathrm{S} 1$ dan $\mathrm{N}$, tanaman jagung pada variabel DS dengan luas lahan berkesesuaian $\mathrm{S} 1$ dan $\mathrm{N}$ serta tanaman ubi jalar pada variabel LQ dengan luas lahan berkesesuaian S2.

Tabel 12. Koefisien korelasi nilai LQ, DS, dan kelas kesesuaian lahan

\begin{tabular}{|c|c|c|c|c|c|c|c|c|c|}
\hline $\begin{array}{l}\text { Komoditas Tanaman } \\
\text { Pangan/ Variabel } \\
\text { Korelasi }\end{array}$ & LQ - DS & LQ - S1 & LQ - S2 & LQ - S3 & LQ - N & DS - S1 & $\mathrm{DS}-\mathrm{S} 2$ & DS - S3 & DS - N \\
\hline Padi Sawah & 0.224 & 0.000 & 0.636 & -0.570 & 0.466 & 0.000 & 0.392 & -0.292 & 0.223 \\
\hline Padi Ladang & 0.460 & 0.110 & 0.359 & -0.227 & -0.107 & 0.736 & 0.018 & -0.431 & 0.597 \\
\hline Jagung & -0.195 & -0.345 & 0.518 & -0.255 & -0.152 & 0.963 & -0.432 & -0.293 & 0.699 \\
\hline Ubi Kayu & 0.543 & -0.340 & -0.530 & 0.546 & -0.344 & 0.292 & -0.405 & 0.122 & 0.117 \\
\hline Ubi Jalar & 0.118 & 0.186 & 0.811 & -0.624 & 0.247 & 0.189 & -0.173 & 0.094 & -0.020 \\
\hline Kacang Tanah & -0.102 & -0.012 & 0.112 & 0.071 & -0.203 & -0.016 & 0.410 & -0.318 & 0.000 \\
\hline Kacang Hijau & 0.007 & -0.218 & -0.090 & 0.490 & -0.517 & 0.235 & -0.312 & 0.413 & -0.247 \\
\hline
\end{tabular}

Keterangan: LQ: location quotient. DS:differential shift. S1: kelas Sangat Sesuai. S2: kelas Cukup Sesuai. S3: kelas Sesuai Marjinal. N: kelas Tidak Sesuai. LQ-DS: korelasi antara nilai LQ dan DS.

Secara umum dapat dinyatakan bahwa budidaya tanaman pangan termasuk diantaranya padi, jagung, ubi kayu, ubi jalar dan kedelai di Provinsi Lampung sebagian besar berlokasi di lahan yang sesuai namun sebagian masih diusahakan di lahan tidak sesuai. Untuk mengoptimumkan produksi dan produktivitas tanaman pangan tersebut, maka upaya pemindahan area tanaman dari lahan yang tidak sesuai perlu dilakukan. Hal ini penting untuk optimalisasi penggunaan bahan serta mencegah terjadinya degradasi lahan dan mengurangi biaya usaha tani karena besarnya hambatan di lahan-lahan tidak sesuai tersebut.

\section{Arahan Pengembangan Komoditas Basis Tanaman Pangan}

Semakin terbatasnya sumberdaya lahan dan keragaman kondisi biogeofisik memerlukan pengaturan dalam pemanfaatan agar lebih efisien dengan memperhatikan prioritas pengembangan komoditas 
pertanian. Untuk itu, masing-masing daerah harus mampu memilih jenis komoditas basis pertanian yang diunggulkan dan diprioritaskan untuk dikembangkan (Mubekti et al., 2006).

Arahan pengembangan berdasarkan hasil perhitungan LQ, DS, tingkat kesesuaian lahan pada kawasan budidaya pertanian menunjukkan Kabupaten Tulang Bawang, Tulang Bawang Barat dan Mesuji memiliki lahan arahan tertinggi untuk dijadikan sentra produksi padi sawah. Hasil evaluasi kesesuaian lahan dari kawasan budidaya di ketiga kabupaten tersebut sebagian besar terdiri dari lahan Sesuai Marjinal (70\%).

Arahan pengembangan padi ladang tertinggi berada di Kabupaten Lampung Utara dengan prioritas urutan pengembangan pertama. Evaluasi kesesuaian lahan dari kawasan budidaya di kabupaten tersebut menunjukkan sebagian besar terdiri dari lahan Cukup Sesuai (59\%). Arahan pengembangan jagung berada di Kabupaten Lampung Timur, Lampung Selatan dan Pesawaran. Evaluasi kesesuaian lahan dari kawasan budidaya di ketiga kabupaten tersebut sebagian besar terdiri dari lahan Cukup Sesuai. Arahan pengembangan ubi kayu berada di Kabupaten Lampung Tengah, Tulang Bawang, Tulang Bawang Barat dan Mesuji. Hasil evaluasi kesesuaian lahan dari kawasan budidaya di kabupaten tersebut sebagian besar terdiri dari lahan Sesuai Marjinal.

Arahan pengembangan ubi jalar berada di Kabupaten Way Kanan. Hasil evaluasi kesesuaian lahan dari kawasan budidaya di kabupaten tersebut sebagian besar terdiri dari lahan Sesuai Marjinal (83\%). Arahan pengembangan kedelai berada di Kabupaten Tanggamus dan Pringsewu. Hasil evaluasi kesesuaian lahan dari kawasan budidaya di kabupaten tersebut terdiri dari lahan Cukup Sesuai (24.5\%), Sesuai Marjinal (44.5\%) dan Tidak Sesuai $(31 \%)$. Arahan pengembangan komoditas basis lainnya di lahan yang tidak besar. Pada kawasan budidaya pertanian masih terdapat lahan tidak sesuai yang direkomendasikan dijadikan kawasan konservasi atau penggunaan lahan lainnya di pedesaan.
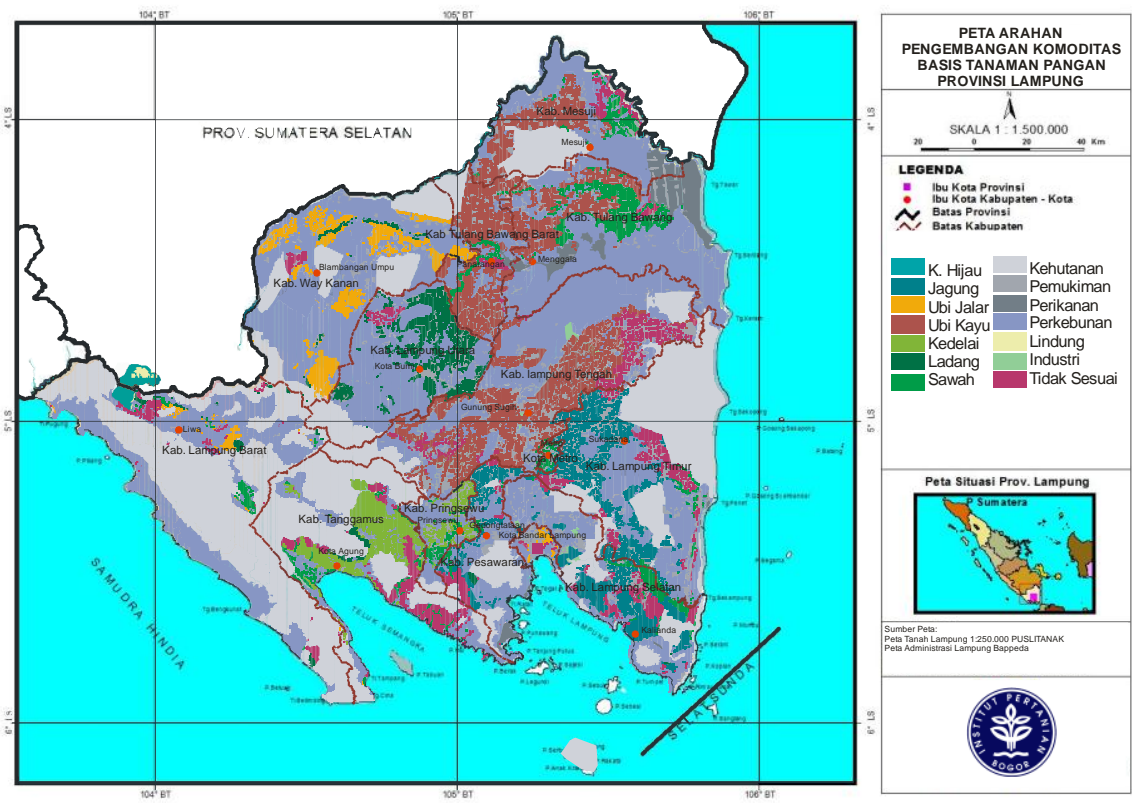

Gambar 6. Peta arahan pengembangan komoditas basis tanaman pangan kawasan budidaya di Provinsi Lampung

\section{SIMPULAN}

Berdasarkan hasil penelitian dan pembahasan yang telah dilakukan dan memperhatikan tujuan dari penelitian ini, dapat disimpulkan hal-hal sebagai berikut:

1. Terdapat komoditas basis tanaman pangan di beberapa kabupaten/kota di Provinsi Lampung yang sebagian besar terdiri dari tanaman padi sawah dan ubi jalar. Kabupaten Tulang Bawang, Mesuji dan Tulang Bawang Barat tidak memiliki komoditas basis tanaman pangan, akan tetapi masih memiliki 2 jenis tanaman yang merupakan keunggulan komparatif yaitu ubi kayu dan padi sawah. Kedua komoditas ini layak dipertimbangkan untuk dikembangkan di ketiga kabupaten tersebut.

2. Terdapat kelas kesesuaian lahan aktual komoditas basis yang berbeda-beda dengan kelas kesesuaian tertinggi sebagian besar pada tanaman padi ladang dan terendah (Tidak Sesuai) pada tanaman padi sawah di Provinsi Lampung

3. Di Provinsi Lampung secara umum dapat dikemukakan bahwa budidaya tanaman pangan termasuk diantaranya padi, jagung, ubi kayu, ubi jalar dan kedelai sebagian besar berlokasi di lahan yang sesuai, meskipun sebagian masih dibudidayakan pada lahan yang tidak sesuai.

4. Pengembangan tanaman padi sawah terutama disarankan di Kabupaten Tulang Bawang, Tulang Bawang Barat dan Mesuji, sedangkan tanaman padi ladang di Kabupaten Lampung Utara. Tanaman jagung disarankan diusahakan di Kabupaten Lampung Timur, Lampung Selatan dan Pesawaran. Tanaman ubi kayu sebaiknya diusahakan di Kabupaten Lampung Tengah, Tulang Bawang, Tulang Bawang Barat dan Mesuji. Tanaman ubi jalar direkomendasikan ditanam di Kabupaten Way Kanan dan tanaman kedelai di Kabupaten Pringsewu dan 
Tanggamus. Lahan yang tergolong kategori tidak sesuai pada kawasan budidaya pertanian disarankan digunakan sebagai kawasan konservasi.

\section{SARAN}

1. Pemerintah daerah dalam menentukan alokasi kawasan pertanian di kawasan budidaya pada rencana tata ruang wilayahnya disarankan agar berdasarkan lahan yang sesuai untuk komoditas basis tanaman pangannya.

2. Pemerintah daerah disarankan dapat mendorong upaya intensifikasi pertanian dengan memperbaiki kualitas lahan dan meningkatkan fasilitas intensifikasi pertanian lainnya untuk meningkatkan produktivitas dan produksi tanaman pangan.

\section{DAFTAR PUSTAKA}

Balai Penelitian Tanah. 2003. Petunjuk Teknis Evaluasi Lahan untuk Komoditas Pertanian. Balai Penelitian Tanah Pusat Penelitian dan Pengembangan Tanah dan Agroklimat Badan Litbang Pertanian, Departemen Pertanian.

[BPS] Badan Pusat Statistik Provinsi Lampung. 2007. Lampung Dalam Angka 2006. BPS Provinsi Lampung. Bandar Lampung.

2008. Lampung Dalam Angka 2007. BPS Provinsi Lampung. Bandar Lampung.
2009. Lampung Dalam Angka 2008. BPS Provinsi Lampung. Bandar Lampung.

2010. Lampung Dalam Angka 2009. BPS Provinsi Lampung. Bandar Lampung.

2011. Lampung Dalam Angka 2010. BPS Provinsi Lampung. Bandar Lampung.

Blakely, E.J. and N.G. Leigh. 2010. Planning Local Economic Development. Theory and Practice. $4^{\text {th }}$ Ed. Sage Publication.

[FAO] Food and Agriculture Organization. 1976. A Framework for Land Evaluation. FAO Soils Bulletin No. 32. FAO. Rome.

Hendayana, R. 2003. Aplikasi metode Location Quotient (LQ) dalam penentuan komoditas unggulan nasional. Informatika Pertanian, 12:1-21.

Imron, A. 2010. Daya saing usahatani jagung hibrida di Kabupaten Lampung Selatan. http://jurnalesai.org/ekonomi-jurnal-18/vol-4-no-1-januari$\underline{2010 .}$

Mubekti, A. Rahmadi, dan S. Ritung. 2006. Teknologi Remote Sensing dan GIS untuk zonasi komoditas dan ketersediaan sumberdaya lahan. Jurnal Sains dan Teknologi Indonesia, 8:124-132.

Walpole, R.E. 1993. Pengantar Statistika. Gramedia. Jakarta. 